\title{
Gold Leaf and Graffiti in a Copy of the 1462 Mainz Bible
}

$\underline{\text { Scott Mandelbrote }}$

University of Cambridge

Cambridge, United Kingdom

Among the books that John Cosin (1595-1672) gave to

Peterhouse, Cambridge, in 1662 is a volume of a large folio

bible in Latin. It is printed in two colors (black and red) on vellum, with extensive penwork in red, blue, green, and purple inks (providing chapter headings, numbers, some initial

letters, highlighting, and rubrication), and has fifty gold initials, mostly infilled with flower motifs in color, at the beginning of each book of the Bible. ${ }^{1}$ Cosin was Master of Peterhouse from 1635 until his ejection by order of Parliament in March 1644. He had returned to Cambridge by June 1660, resuming the mastership until November. On December 2, 1660, he was consecrated as bishop of Durham. ${ }^{2}$ Royalist in politics and ritualist in religion, Cosin was one of the most indefatigable and successful book collectors and library builders of seventeenth-century England. ${ }^{3}$ During his mastership, in the late 1630s, the library of Peterhouse was rebuilt and extended, and work began on new shelves and panelling, as well as a new catalogue. ${ }^{4}$ Following the sequestration of Cosin's books after he had fled from Parliamentarian Cambridge during the English Civil War, his successor as Master, Lazarus Seaman, petitioned to have them 
settled at Peterhouse. As a result, over a thousand volumes were transferred to the shelves of the college. ${ }^{5}$ These books remained in dispute when Cosin returned to England: by December 1660, they had been removed to the custody of the new Master of Peterhouse, Bernard Hale. Missing volumes were being pursued with those who had borrowed them. 6 Some sort of settlement was reached in 1662: the Latin folio bible is one of several to bear a donation inscription from Cosin dated in that year. Many books left Peterhouse for Durham, including a copy of the first folio of Shakespeare. ${ }^{7}$ Near the end of his life, cosin nevertheless claimed to have given to Peterhouse "1031 volumes of good books, fairely and well bound; which cost him about 3001i."8 The actual number, as Hale later determined, was 1,174.

The binding on Perne Library, shelfmark S. 10b, is no longer fair: it was renewed in cheap and thin calf over inadequate pasteboards in 1830, as a note on the pastedown of the front board (signed "E[dward] V[entris]") makes clear.9 That note also identifies the book, with the help of Thomas Frognall Dibdin's catalogue of the library of his patron, the second Earl Spencer. It is a copy of the second volume of the 48-line Latin bible printed by Johann Fust and Peter Schoeffer at Mainz in 1462, and thus half of what we now know to be the fourth edition (Dibdin believed it to be the third) of the printed Vulgate, first published by Johann Gutenberg in the same German city less than a decade before. ${ }^{10}$ In later 
nineteenth-century catalogues of the library at Peterhouse, the volume is recorded in a fashion that reflects this identification, and that also notes the presence of a contemporary manuscript of biblical exposition bound with the printed book.11

This raises the first puzzle about the volume. What did Cosin think he had given Peterhouse and what did the college think it had received? The colophon, which should have identified the book quite straightforwardly, has been erased in this copy, leaving only the printer's mark clearly visible (see fig. 1).12 The leaf bearing the colophon (fol. 239r) is then followed by thirty leaves of manuscript, in a hand that superficially resembles the typeface designed by Schoeffer and used to print the 1462 Mainz bible, and with decoration that is also similar to that of this copy of the printed text. ${ }^{13}$ The manuscript, whose last column is crammed into the bottom margin of the verso of the final leaf of the volume, is a roughly alphabetical list of approximately 5,500 personal and place names that occur in the Latin bible with translations of the meaning of the original Hebrew words from which they were taken. Having initially circulated independently at the start of the thirteenth century, this text (the Interpretation of Hebrew Names) was frequently supplied from about 1230 as an appendix to manuscript Latin bibles, for which it served as a readily usable and brief allegorical gloss. Its first compiler is often said to be Stephen Langton (d. 1228).14 
The catalogue of Cosin's library made in connection with the seizure and transfer of his books to Peterhouse does not contain an unambiguous reference to the second volume of the 1462 Mainz bible, although a shelfmark ("Ex Parte Bor[eali] E Dext[era] C[lassis] 7 F[igura] 1 L[iber] 3") that is consistent with those found in many other books listed in the catalogue is written on its first folio (see fig. 2). The second volume of the 1462 Mainz bible opens with Jerome's letter concerning the writings of Solomon and the start of Proverbs. There is an otherwise obscure entry in the catalogue of Cosin's library to a book of Proverbs (valued at 3s. 6d.). Certainly, "Proverbia Solomonis" is how the volume was subsequently recorded in seventeenth- and eighteenth-century catalogues of the library at Peterhouse (where it has the shelfmark "f[olio] A[ustralis] 02/05/01" and is recorded as a gift from Cosin). ${ }^{15}$ Additionally, however, the cataloguers who based themselves on the work of John Woodward (admitted to Peterhouse in 1677 and a fellow from 1683 until 1693), described the book as being a manuscript, even though they listed it and shelved it among other printed books given by $\operatorname{Cosin} .16$

This is an intriguing misidentification for a number of reasons. First, it underscores the fact that cosin and his contemporaries were uncertain both about how to recognize the earliest printed books and about their attribution. Indeed, the identity of the first printed book, the location of its 
production, and the name of its printer were all subjects of heated debate in print during the 1640s and 1650s. Among the candidates were Fust and Schoeffer in Mainz and a bible printed no later than 1462 (but possibly begun as early as 1450 and perhaps completed in 1459), as well as Gutenberg himself and rivals in Haarlem and Strassburg. ${ }^{17}$ By coincidence, Cosin arrived as an exile in Paris in the very year in which the Carmelite Louis Jacob de Saint-Charles published an account of libraries. There Jacob described the 1462 Mainz bible as one of the first two printed books, produced by Fust as the true inventor of the craft, and located two copies, in the Parisian libraries of the Carmelites at Place Maubert and of the Priory of Sainte-Croix de la Bretonnerie. ${ }^{18}$ It is striking to think that Cosin might by then himself have owned a copy of this book, without realizing the significance that it had already acquired in the literature on the history of printing. In the early eighteenth century, one of those who repeated that the 1462 Mainz bible was the earliest printed text of the Vulgate was the Oratorian bibliographer, Jacques Le Long. Le Long also referred to differences in the colophons of several Parisian copies of the book and suggested that the absence of explicit reference to printing in one version (in the collection of the Président of the Parlement, Achille de Harlay) gave substance to the tale that Schoeffer had sold copies of the book in Paris as a fine manuscript. The experience of Cosin and of the Peterhouse libraries provides 
additional evidence for ongoing confusion about the intentions of the earliest Mainz printers and the status of the work that they produced. ${ }^{19}$

The first known English purchaser of a book published by Fust and Schoeffer (or indeed any other printed book) was James Goldwell, fellow of All Souls College, Oxford, who acquired a copy of Durandus's Rationale divinorum, printed at Mainz in 1459, at Hamburg in 1465.20 It is possible that copies of the 1462 Mainz bible also came to England in the fifteenth century. ${ }^{21}$ Nevertheless, Cosin's book may well have been the only extant copy of the book there in the seventeenth century. ${ }^{22}$ On the first leaf of the printed text is a manuscript inscription (see fig. 2): "Edo Orwell. 1581. ex dono Justiniani Kidd." The location of the inscription strongly suggests that in 1581 this (second) part of the 1462 Mainz bible was already separated from the first volume that had once accompanied it. Both Edward Orwell, to whom the book was given, and Justinian Kidd (its first known owner) can be identified with some certainty. They were lawyers: Kidd (d. ca. 1599) acted as a proctor in Doctors' Commons and as executor to a number of wills; Orwell (d. 1591) had been apprenticed as a notary to Anthony Hussey and served as registrar of the Court of Arches. ${ }^{23}$ In the London Subsidy Roll for 1582, both Kidd (£15) and Orwell (£30) were assessed in the Ward of Farringdon Within. Kidd at the time lived in the parish of St. Faith; Orwell in the nearby parish of Christ 
Church. ${ }^{24}$ There is other evidence that Orwell was interested in books: from the will of John Lewes in which he was given a choice of the testator's books; from a copy of Angelo de Clavisio's Summa angelica (Strassburg, 1513) that Orwell acquired in 1584 and that is now in the library of Westminster Abbey; from a fourteenth-century manuscript of Ralph Higden's Polychronicon that he owned and that made its way after 1613 and before 1620 to the newly founded Bodleian Library in Oxford; and from two manuscripts that entered the collections of the archbishops of Canterbury in the first half of the seventeenth century. The manuscripts now at Lambeth are a fifteenth-century copy of the agricultural manual (Liber ruralium commodorum) of Petrus de Crescentiis, and a thirteenth-century collection, mostly of chronicles, once in the library of Reading Abbey, that Orwell acquired, probably from Clement Burdett, on March 19, 1577.25 Orwell signed his name in the last book on a folio that consisted of a letter from Alured, sacrist of Reading, which described a little manuscript of the bible that been stolen from the abbey's cloister in July 1253 and whose recovery was now being sought on pain of excommunication. ${ }^{26}$

The copy of the 1462 Mainz bible that Kidd gave to Orwell is notable for the extensive illumination that it contains. This features fifty gold initials that mark the beginning of each book of the Bible; they are mostly infilled with colored flower motifs on blue or magenta grounds with white patterning 
(see fig. 3). The opening historiated initial, for Proverbs, depicts King Solomon, as a young man, crowned and dressed in a short contemporary costume of gold and scarlet with blue stockings, standing on a green background (see fig. 2). The painting of the initials can be localized to Cologne, as can the decoration and penwork of four other surviving copies of the 1462 Mainz bible. ${ }^{27}$ of these, three others also contain at least one historiated and many floral initials. Both the historiated initial and the floral initials in the copy at Peterhouse have been thought reminiscent of their counterparts in a complete copy of the 1462 Mainz bible now in the Universitätsbibliothek in Frankfurt, which probably belonged to Heinrich Schultheissen, canon of the imperial collegiate church of St. Bartholomew, and which may have been illuminated by a follower of the artist Stefan Lochner. In 1483, Schultheissen and the dean of St. Bartholomew, Conrad Vasbender, each gave illuminated copies of the 1462 Mainz bible, printed on vellum, to their church. The two volumes of the copy belonging to Vasbender, who matriculated at the University of Cologne in 1466, are now in the British Library, and have seven historiated initials and numerous floral initials which have some similarities to those found at Peterhouse. ${ }^{28}$

Illumination was one of the strategies which helped to ensure the successful sale of the 1462 Mainz bible in Germany, despite the availability of several earlier editions of the 
Vulgate. The provision of gold leaf decoration, however, in the copy at Peterhouse initially encouraged its later readers to see this printed book as a manuscript and later promoted a very different kind of engagement with its text and illustrations. The library at Peterhouse had once contained a large number of manuscripts with some form of illumination or decoration. Most of these books were subjected to extensive iconoclasm, probably in the sixteenth century. As a consequence, very few pictures and very little gold leaf survive among the college's holdings of medieval manuscripts, even though these preserve the majority of its fifteenthcentury library. ${ }^{29}$ Two manuscripts, however, entered the library in 1660 and 1661, as part of a gift of books from Algernon Peyton (d. 1667), rector of Doddington and fellow commoner of Peterhouse. In both of these, the illumination survives unscathed. ${ }^{30}$ This is largely true also for Cosin's copy of the 1462 Mainz bible, from which, however, three floral initials have been excised (at folios 192, 196, and 201: see fig. 4) and two partially removed (at folios 12 and 230). Such neat removals are suggestive of the appetite for collecting specimens of medieval miniatures among late eighteenth-century bibliophiles. ${ }^{31}$

Eighteenth-century users of Cosin's copy of the 1462 Mainz bible left their mark on the book in a more singular manner. Between 1594 and 1613, sixteen choristers of the Church of the Holy Cross (Heilig-Kreuz-Kirche) in the 
southwest German city of Offenburg wrote their names in the interior of the initials and in the margins of their foundation's copy of what is now known to be the first printed book, the 42-line Gutenberg bible.32 In 1877, Christopher Wordsworth (1848-1938) posited an unconscious echo of such activity in the very different community of Peterhouse, as part of his description of the visit of the eighteenth-century Frankfurt bibliophile, Zacharias Conrad von Uffenbach, to Cambridge in 1710. Uffenbach was dismissive of many college collections, including those at Peterhouse, which he regarded as out-dated, tedious, and poorly maintained. Wordsworth repeated Uffenbach's censure of the librarians of Pembroke, who had allowed cuttings to be taken from an illuminated manuscript of Aulus Gellius, and added his own observations: "In Peterhouse library the gilding \&c. of some of the initials of Fust and Schoeffer's Latin Bible (Mentz, 1462) has been scratched and mutilated in days when even choristers were allowed free access to the room, which was in sad disorder when Uffenbach visited it, Aug. 7, 1710. One of the offenders (a freshman or a junior soph) has left not only his name but the date of his indenture in the burnished gold-[Jacques] 'Spearman, 1732.'"33

Unlike the Church of the Holy Cross in Offenburg, Peterhouse had no choral foundation in the eighteenth century. Formally, access to the library was limited to fellows of the college, who could and did borrow books on behalf of their 
undergraduates. A particular group of scholars, however, principally consisting of those who were in receipt of funds deriving from a bequest made in the late sixteenth century by Andrew Perne (Master of Peterhouse from 1555 until his death in 1589), were charged with the upkeep of the library, including stock checks and cataloguing. ${ }^{34}$ From examination of Cosin's copy of the 1462 Mainz bible, it is possible to trace the abuse of such access by a group of scholars of Peterhouse and their friends in the early 1730s. For these readers of the book, its attraction indeed lay in the suitability of gold leaf as a background on to which names and insults could be scratched as graffiti. Their activity cannot be paralleled in any of the college's (admittedly inaccessible) manuscripts and thus seems to have been confined to the serendipitous discovery of the possibilities provided by such an incomplete quasi-manuscript, which could be found shelved among the college's printed books. They carefully chose places to write which were in the middle of the volume, perhaps to reduce the chance of detection or perhaps to increase the thrill of shared discovery. Whether the graffiti that they wrote indicated any disrespect for the Latin Vulgate text of the Bible is unknowable. Certainly, it showed a healthy contempt for the moral character of their friends.

The graffiti read as follows:

1. (initial to Jeremiah, fol. 53v): Pimp PORTEUS (see fig. 
2. (initial to Lamentations, fol. 74v): COOK Fool

3. (initial to Baruch, fol. 76v): Spearman 1732 (see fig. 6)

4. (initial to Daniel, fol. 99r): P. Clennell Trin. Coll. 1735 (see fig. 7)

5. (initial to Joel, fol. 109v): Spearman

6. (initial to Amos, fol. 110v): Spearman

7. (initial to Abdias [Obadiah], fol. 112v): WARD

8. (initial to Jonah, fol. 113r): WARD

9. (initial to Habakkuk, fol. 115v): P. Clennell [repeated]

10. (initial to Zachariah, fol. 118r): Wm Wade

11. (initial to Galatians, fol. 200r): Allenson

[possible reading]

12. (initial to 1 John, fol. 231r): Coyte Beaumont 1730 Who were the writers involved? Charles Beaumont was the son of the rector of Witnesham, Suffolk, and had been educated at Ipswich School before matriculating at Peterhouse, aged sixteen, on March 7, 1727. He was elected to two scholarships, in 1727 and 1729, took his B.A. in 1730 and proceeded M.A. in 1734, by which time he was Perne fellow (1733-36). He was ordained deacon and later priest in 1736 and succeeded his father as rector of Witnesham, where he died in 1756.35 Beaumont's partner in crime was probably Beeston Coyte (rather than his brother, William). Both Coyte brothers matriculated at Peterhouse on February 17, 1727, but William (b. 1708) was two or three years older than his brother and embarked on a medical career (M.B. 1732). Beeston entered the college as a 
sizar at the age of sixteen, was a scholar, and took his B.A. in 1730. The Coyte brothers again came from Suffolk, where they were neighbours of Thomas Gainsborough at Sudbury, and had also studied at Ipswich School. ${ }^{36}$ During their time at Ipswich, the remarkable town library, which was in the care of the schoolmaster, was enriched by the acquisition of books that had belonged to the Parliamentarian iconoclast William Dowsing (1596-1668), who in December 1643 had presided over the pulling down of statues and images in the chapel at Peterhouse. ${ }^{37}$ Beeston Coyte died at Kingston, Jamaica, in 1776 and was memorialized in terms which may strike readers with some irony:

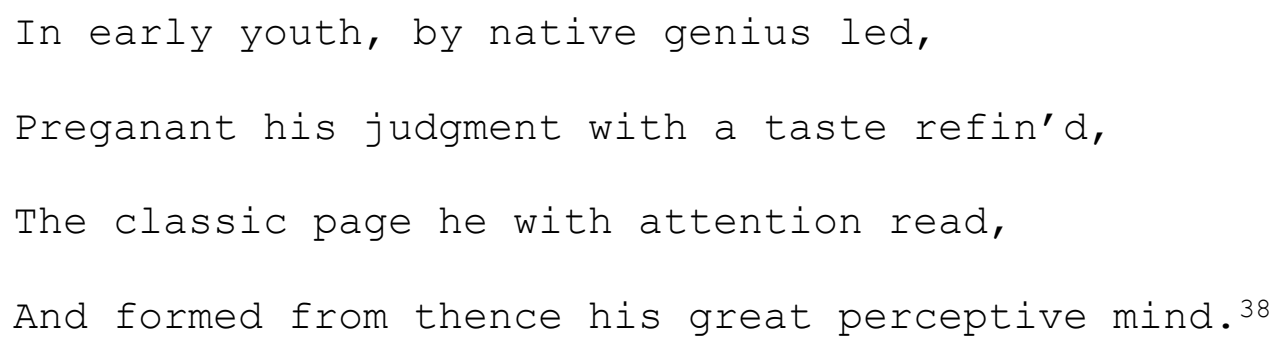

Robert Porteus (ca. 1705-1754) was rather older than the members of this suffolk trio and seems to have been born in Virginia. He was educated at a private school in Twickenham 
and entered Peterhouse aged twenty in October 1725 as a sizar. He became successively North scholar and Hale scholar and took his B.A. in 1729, in which year he was also ordained a deacon. He proceeded M.A. in 1738, by which time he was rector of Hatley in Cambridgeshire. ${ }^{40}$ Jaques Spearman (1713-1745) came from County Durham and was educated at Houghton-le-Spring before matriculating as a sizar at Peterhouse, aged eighteen, in July 1731. He held a number of scholarships before graduating B.A. in 1734. He was ordained as a deacon from Ely in December 1735 and pursued an unsuccessful clerical career, latterly at Royston in Hertfordshire. His distant relative, George Spearman (1714-1761), had already begun his studies at Gray's Inn when he was admitted as a fellow commoner at Peterhouse in December 1731. ${ }^{41}$ Percival Clennell (d. 1743), who was admitted as a pensioner at Trinity College in October 1733 at the age of seventeen, was from a Northumberland family, and like Jaques Spearman, he had been educated at Houghton-leSpring. In January 1735, he was admitted to the Middle Temple. ${ }^{42}$

The identities of William Wade, Mr. Ward, and Mr. Allenson are harder to establish with certainty. William Wade (ca. 1692-1728) came up to Peterhouse in 1710 and became vicar of Standon, Hertfordshire. His son, also William, matriculated at Christ's in 1743, aged nineteen. If neither of these seem especially likely candidates, then neither does a third William Wade. He was admitted as a sizar at Clare College in 
June 1721, having been at school in his native Wakefield, Yorkshire. He took his B.A. in 1725 and proceeded M.A. in 1731, by which time he may have been Master of Chichester Grammar School. ${ }^{43}$ Ward is such a common surname that it is really impossible to make reasonable suggestions: nobody of that name seems to have been at Peterhouse at the relevant moment, whereas there were several Wards at other colleges (including more than one at Trinity). There were members of Peterhouse named Allenson in the seventeenth century, but their family appears to have had stronger associations with St. John's College. A more probable author of the inscription here might be Gilbert Allenson, who was admitted to st. John's College aged nineteen in June 1729, and who took his B.A. in 1732-33.44 There may also be other names recorded as graffiti elsewhere in the gold leaf of Cosin's copy of the 1462 Mainz bible, but scratches made on other initials (e.g., fol. 206v) have so far not proved to be decipherable. Despite such disappointments, it is possible to draw one or two conclusions from this prosopography of vandalism. First, the writers of graffiti who can be identified with certainty were almost all young men, either scholars or very recent Bachelors of Arts. Secondly, they were close friends, who in several cases had been to school with one another. This connection almost certainly explains how Percival clennell of Trinity college came to write his name in a book at Peterhouse. Something like it may also account for the 
puzzling presence of William Wade and Mr. Ward. Although some became lawyers, most were ordained shortly after defacing the gold leaf in this bible with jests that one assumes they did not hold in any way to constitute a form of blasphemy. Third, there were repeat offenders, and the defacement of the book took place on three or more occasions, separated by at least five years (Beaumont and Coyte in 1730; Spearman i 1732; 1735: Clennell and presumably spearman again in 1735). It is tempting to assume that the inscriptions of Porteus and cooke were also written together, perhaps as early as 1729. Here other records of the library at Peterhouse help to flesh out the opportunities provided for mischief and amusement. In 1730, both Charles Beaumont and Beeston Coyte were among the scholars responsible for keeping the register of books borrowed and returned to the library, as was Jaques Spearman in 1735.45 In their treatment of Cosin's copy of the 1462 Mainz bible, Beaumont, Coyte, and spearman were thus gamekeepers turned poachers.

In a different context, Jaques Spearman was mocked for his errors of learning. In 1740, he attacked the high Calvinism of the Independent minister of Royston, Thomas Gibbons (ca. 1700-1757). Spearman accused Gibbons of lacking any education beyond the ability to read a chapter in the Bible "if there were no hard Words in it," to which his opponent responded: "had I, with all my private and mean Education, been guilty of such rude, unmannerly speeches at 
seven Years of Age, I should have had the Rod shook over me; but see the Difference between a private and inferior Education, and such a public and eminent one as Jaques Spearman's!" For Gibbons, almost every page of Spearman's work was "a lasting Monument of Ill-nature, Passion, and Folly." There was one exception: "the Glory of the Book. And what Page is it? Why truly the Blank-side between the Title Page and the Letter itself. And a very good Reason there is for this being so unexceptionable, since there is neither syllable nor Letter in it." 46

Confronted with the hard words of the 1462 Latin bible, Spearman failed to keep silent, writing himself on the blank spaces provided by its burnished gold illuminations. In so doing, he clandestinely broke the rules that bound his conduct as a poor scholar and responsible junior member of the society of his college. He did so as part of an affirmation of friendship rather than a challenge to religion. In the process, he helped to transform this particular copy of the book into one that can speak in multiple voices across generations.

Captions

Figure 1.

Erased colophon of the 1462 Mainz bible, Peterhouse, Perne

Library, shelfmark S. 10b, fol. 239r. Reproduced with the permission of the Master and Fellows of Peterhouse, Cambridge. 
Figure 2.

Opening folio of volume two of the 1462 Mainz bible showing an illumination of King Solomon and the donation inscription from Justinian Kidd to Edward Orwell in 1581, as well as a seventeenth-century shelfmark. Reproduced with the permission of the Master and Fellows of Peterhouse, Cambridge.

Figure 3 .

1462 Mainz bible, fol. 19v, showing a detail of floral

decoration and illumination. Reproduced with the permission of the Master and Fellows of Peterhouse, Cambridge.

Figure 4.

1462 Mainz bible, fol. 201v, showing an excised initial.

Reproduced with the permission of the Master and Fellows of

Peterhouse, Cambridge.

Figure 5 .

1462 Mainz bible, fol. 53v: graffito reading "Pimp PORTEUS."

Reproduced with the permission of the Master and Fellows of

Peterhouse, Cambridge.

Figure 6. 
1462 Mainz bible, fol. 76v: graffito reading "[Jaques]

Spearman 1732." Reproduced with the permission of the Master

and Fellows of Peterhouse, Cambridge.

Figure 7 .

1462 Mainz bible, fol. 99r: graffito reading "P[ercival]

Clennell/ Trin[ity] Coll[ege] 1735." Reproduced with the

permission of the Master and Fellows of Peterhouse, Cambridge.

\section{Notes}

I am grateful to Paul Needham, James Marrow, Ines Dickmann, Stella Panayotova, Azurra Andriolo, and James Carley for discussion of the Perne Library's copy of the 1462 Mainz bible and its illumination.

1 Cambridge, Peterhouse, Perne Library, shelfmark S. 10b. See also C[osmo] G[ordon], Early Printed Books to the Year 1500 in the Library of Peterhouse, Cambridge (Cambridge: Cambridge University Press, 1914), 4 .

2 For Cosin's career, see Anthony Milton, "Cosin, John (15951672), bishop of Durham," Oxford Dictionary of National Biography (Oxford: Oxford University Press, 2004).

3 A. I. Doyle, "John Cosin (1595-1672) as Library Maker," The Book Collector 40 (1991): 335-57; the book under discussion here is mentioned (354) but incorrectly described. For a 
correction, see A. I. Doyle, "Corrigendum," The Book Collector 41 (1992): 263.

4 Simon Bradley and Nikolaus Pevsner, The Buildings of England: Cambridgeshire (New Haven, Conn.: Yale University Press, 2014), 172; Cambridge, Emmanuel College, MS 3.1.20 (a catalogue of the library at Peterhouse, in which the latest identifiable entry was made in 1643).

5 Peterhouse Archives, Bibliotheca Box ("Passages concerning Dr. Cosin's Library" and "Catalogue of Dr. Cosin's Library"). Cosin's books were valued at more than three times the worth of the next largest collection of books seized by the sequestrators in Cambridge; see James Bass Mullinger, The University of Cambridge, Volume 3: From the Election of Buckingham to the Chancellorship in 1626 to the Decline of the Platonist Movement (Cambridge: Cambridge University Press, $1911), \quad 280-82$.

6 George Ornsby, ed., The Correspondence of John Cosin, 2 vols. (Durham, 1869-72), 2:13-14.

7 Later, this Shakespeare first folio entered Durham, Bishop Cosin's Library, as shelfmark W.2.11. This volume has acquired more recent notoriety through its theft by Raymond scott in December 1998, its subsequent identification by the Folger Shakespeare Library in 2008, and its return to Durham in July 2010. Scott committed suicide in prison in March 2012. See also Anthony James West, The Shakespeare First Folio: The History of the Book, 2 vols. (Oxford: Oxford University Press, 
2001-3), 2:84-85; Eric Rasmussen and Anthony James West, eds., The Shakespeare First Folios: A Descriptive Catalogue

(Basingstoke, Hampshire: Palgrave Macmillan, 2012), 25 (where Scott is oddly described as an "owner" of this copy).

8 Ornsby, ed., Correspondence of Cosin, 2:173 (written in 1668); see 301 (Cosin's will).

9 Edward Ventris (1802-86), antiquarian and perpetual curate of Stow-cum-Quy, entered Peterhouse in 1821; see Thomas Alfred Walker, Admissions to Peterhouse or S. Peter's College in the University of Cambridge . . 1615 to 1887 (Cambridge: Cambridge University Press, 1912), 412.

10 See Thomas Frognall Dibdin, Bibliotheca Spenceriana; Or a Descriptive Catalogue of the Books Printed in the Fifteenth Century . . . in the Library of George John Earl Spencer, 4 vols. (London, 1814-15), 1:11-18. Spencer's copy is now Manchester, John Rylands University Library, shelfmark Inc. 3070. Dibden had seen five copies of the book in England, none of which were in Cambridge. His notebook of a visit to Cambridge in 1823 does not mention books at Peterhouse; see Thomas Frognall Dibdin, Horae Bibliographicae Cantabrigienses: A Facsimile of Dibdin's Cambridge Notebook 1823, ed. Renatto Rabaiotti and David McKitterick (New Castle, Del.: Oak Knoll, 1989). Charles Henry Hartshorne ("a young thorough-bred bibliomaniacal Racer" according to Dibdin) claimed to find a copy in the Cambridge University Library (C. H. Hartshorne, The Book Rarities in the University of Cambridge [London, 
1829], 129), but this appears to have been a ghost, possibly confused with a copy of the 1476-77 Paris bible with a damaged colophon, which had long puzzled cataloguers and readers. The University Library first acquired a fragment of the 1462 bible in 1892 and a largely complete copy of both volumes in 1933; see J. C. T. Oates, A Catalogue of the Fifteenth-Century Printed Books in the University Library Cambridge (Cambridge: Cambridge University Press, 1954), 19, 64-65, 484. 11 See Peterhouse MS 420, describing the book under shelfmark A.2.10. The first complete published notice appears in samuel Sandars, An Annotated List of Books Printed on Vellum to be Found in the University and College Libraries at Cambridge (Cambridge, 1878), 41. This is the basis for future descriptions, for example, W. A. Copinger, Incunabula biblica (London, 1892), 16; and Seymour de Ricci, Catalogue raisonné des premières impressions de Mayence (1445-1467) (Mainz: Gutenberg Gesellschaft, 1911), 91. In 1892, Sandars himself acquired from the Munich firm of Ludwig Rosenthal the residue of a copy of volume 2 of the 1462 Mainz bible that had been split by booksellers and a leaf from volume 1: these are both now in the Cambridge University Library (see Oates, Catalogue, $64)$.

12 There are in fact three different settings of the colophon in surviving copies of the 1462 Mainz bible, all printed in the secondary red-ink formes for those pages. This copy has the first, seven-line state with the same wording that had 
been used by Fust and Schoeffer in their earlier publications; see Paul Needham, "The 1462 Bible of Johann Fust and Peter Schöffer (GW 4204): A Survey of Its Variants," GutenbergJahrbuch 81 (2006): 19-49, at 38-41.

13 For Schoeffer's typeface and its resemblance to his own hand, see Hellmut Lehmann-Haupt, Peter Schoeffer of Gernsheim and Mainz (Rochester, N.Y.: Leo Hart, 1950), 20-22.

14 On this text, see Christopher de Hamel, The Book: A History of the Bible (London: Phaidon, 2001), 122-23; for other versions of it at Peterhouse, see R. M. Thomson, A Descriptive Catalogue of the Medieval Manuscripts in the Library of Peterhouse, Cambridge (Cambridge: D. S. Brewer, 2016), 25-26, 67-68 (MSS 44 and 45 [both Latin bibles], 119 [a collection of biblical commentaries]).

15 See shelfmark f[olio] A[ustralis] 02/05/01 in these catalogues in Peterhouse, MS 408 (compiled in 1686); MS 409 (compiled in 1707/8); MS 410 (before 1693); and MS 412 (compiled in 1760).

16 See Peterhouse MSS 408, 409, and 410 ( MS 412 omits this information); Walker, Admissions to Peterhouse, 158-59.

17 Paul Needham, "The Discovery and Invention of the Gutenberg Bible, 1455-1805," in The Medieval Book: Glosses from Friends and Colleagues of Christopher de Hamel, ed. James H. Marrow, Richard A. Linenthal, and William Noel ('t Goy-Houten, Neth.: Hes and De Graaf, 2010), 208-41; see also Lotte Hellinga- 
Querido and Clemens de Wolf, Laurens Janszoon Coster was zijn naam (Haarlem: Enschedé, 1988), 81-82.

18 Louis Jacob de Saint-Charles, Traicté des plus belles bibliotheques publiques et particulieres. . . dans le monde, 2 vols. (Paris, 1644), 2:532-33. These copies are now Munich, Bayerische Staatsbibliothek, shelfmark $2^{\circ}$ L. impr. m. 11; and Paris, Bibliothèque nationale de France, shelfmark Vélins 7376. See Eberhard König and Heribert Tenschert, Biblia pulchra: Die 48zeilige Bibel von 1462 . . mit einem Census der erhaltenen Exemplare (Ramsen, Switz.: Tenschert, 2005), 258, $282-83$.

19 Jacques Le Long, Bibliotheca sacra, 2 vols. (Paris, 1723), 1:250-51. See also Needham, "The 1462 Bible," 10-11. 20 Oxford, All Souls College, shelfmark L.R. 5. 1. 1 (where it has been since 1498); see Ian Maclean, All Souls Library, 1438-2008: Buildings, Collections, Donors (Oxford: All Souls College, 2008), 5-7; N. R. Ker, Records of All Souls College Library, 1437-1600 (Oxford: Oxford Bibliographical Society, 1971), 107, 162.

21 According to König and Tenschert, Biblia pulchra, 76-77, 309, a leaf now in Akron, Ohio, has been localized on the basis of its illumination to fifteenth-century London; and Oxford, Bodleian Library, shelfmark Auct. M. 1. 4-7 (which, following a long tradition, is mistakenly identified with Harlay's copy) bears annotations that appear to be by an English Dominican (see 269-70). See also Lotte Hellinga, 
"Importation of Books Printed on the Continent into England and Scotland before c. 1520," in Printing the Written Word: The Social History of Books, ca. 1450-1520, ed. Sandra L. Hindman, ed. (Ithaca, N.Y.: Cornell University Press, 1991), 205-24; Vincent Gillespie, "Syon and the English Market for Continental Printed Books: The Incunable Phase," in Syon Abbey and Its Books: Reading, Writing, and Religion, c. 1400-1700, ed. E. A. Jones and Alexandra Walsham (Woodbridge, Suffolk: Boydell Press, 2010), 104-28, at 116-17; Alan Coates et al., $\underline{A}$ Catalogue of Books Printed in the Fifteenth Century Now in the Bodleian Library, 6 vols. (Oxford: Oxford University Press, $2005), 2: 450$.

22 By the first half of the eighteenth century, it is possible to trace several copies of the 1462 Mainz bible owned in England: the copy of Sir Richard Ellys (1682-1742) at Blickling Hall, Norfolk, probably acquired from the canons regular of the Holy Cross in Cologne (König and Tenschert, Biblia pulchra, 296-98), now in the Library of Congress, Washington D.C.; the copy of Charles Spencer, 3rd Earl of Sunderland (1674-1722) at Sunderland House, London, probably acquired in France and bound for Sunderland in 1711 (König and Tenschert, Biblia pulchra, 264-65), now in the New York Public Library; and the copy of Richard Mead (1673-1754) in London, acquired from the Mainz Charterhouse in about 1725 (König and Tenschert, Biblia pulchra, 237-38), now in the Museum Meermanno-Westreenianum, The Hague. Others have been 
identified, on the basis of mentions in the catalogues of auctions and booksellers, by De Ricci, Catalogue raisonné, 968: Edward Harley, 2nd Earl of Oxford (1689-1741) (whose copy may have passed to Brian Fairfax (1676-1749)) and the bookseller, James Woodman (in London, 1733). The auction price of the 1462 Mainz bible reached $£ 120$ in 1718; see also Anna Katherine Swift, "The Formation of the Library of Charles Spencer, 3rd Earl of Sunderland (1674-1722): A Study in the Antiquarian Book Trade" (D.Phil. thesis, University of Oxford, $1986), 26-30,40-41$.

23 Kew, The National Archives, PROB 11/93/28 (Justinian Kidd); PROB 11/79/159 (Edward Orwell); Thomas F. Mayer and Courtney B. Waters, The Correspondence of Reginald Pole, Volume 4: A Biographical Companion; The British Isles (Aldershot, Hampshire: Ashgate, 2008), 291-93; E. A. Fry, ed., Abstracts of Inquisitiones Post Mortem for the City of London: Part 3 (London: British Record Society, 1908), 163-64.

24 R. G. Lang, ed., Two Tudor Subsidy Assessment Rolls for the City of London, 1541 and 1582 (London: London Record Society, 1993), 228, 231. Kidd left $£ 10$ to the poor of St. Faith's parish; see John Stow, A Survey of the Cities of London and Westminster, ed. John Strype, 2 vols. (London, 1720), vol. 1, bk. 3, 147. See also Willoughby A. Littledale, ed., The Registers of Christ Church, Newgate, 1538 to 1754 (London, 1895), 28, 32, 34 (for the birth of Orwell's children, Edward, Anne, Thomas, and Elizabeth). For the younger Edward, also a 
notary, see The National Archives, PROB 11/159/355; for Anne, later the adulterous wife of John Overall, dean of St. Paul's, see John Aubrey, Brief Lives, ed. Kate Bennett, 2 vols.

(Oxford: Oxford University Press, 2015), 1:685-86, and 2:164447, where her brother is however confused with her father. 25 See Mayer and Waters, Correspondence of Reginald Pole: Volume 4, 334-35; London, Westminster Abbey, shelfmark G. 4. 30 (formerly in the library of the Augustinian Priory of st. Mary Overy, Southwark); Bodleian Library, MS Bodl. 341 (inscribed "Edo. Orwell. 17. Martij 1577"); R. W. Hunt, $\underline{A}$ Summary Catalogue of Western Manuscripts in the Bodleian Library at Oxford, Volume 1 (Oxford: Clarendon Press, 1953), 103; London, Lambeth Palace Library, MS 174 (inscribed "Edo: Orwell: 13 Julii 1586"; this was later owned by Archbishop Bancroft [1544-1610]: see MS LF/F/1, fol. 69r); Lambeth Palace Library MS 371 (inscribed "Edw. Orwell 19. Marcii 1577"); Alan Coates, English Medieval Books: The Reading Abbey Collections from Foundation to Dispersal (Oxford: Clarendon Press, 1999), 137, 156. I am grateful to James Carley for information about Bancroft's library.

26 Lambeth Palace Library, MS 371, fol. *1r, printed in Coates, English Medieval Books, 83.

27 For details of these copies, see König and Tenschert, Biblia pulchra, 225-26 (Darmstadt, Universitäts- und Landesbibliothek, shelfmark Inc. V 15), 232-33 (Frankfurt-amMain, Universitätsbibliothek Johann Christian Senckenberg, 
shelfmark Inc. fol. 103), 241-43 (London, British Library, shelfmark IC 102), 292 (Vatican City, Biblioteca Apostolica Vaticana, shelfmark Membr. S. 13-14), and see 212-13 for the Peterhouse copy

28 For discussion of these points, I am grateful to James Marrow and Ines Dickmann; Eberhard König, "New Perspectives on the History of Mainz Printing: A Fresh Look at Illuminated Imprints," in Printing the Word, ed. Hindman, 143-73, at 16163. See also Hermann Keussen, Die Matrikel der Universität Köln. Erster Band, 1389-1475, 2nd ed. (Bonn: P. Hanstein, 1928), 743; Kurt Ohly and Vera Sack, Inkunabelkatalog der Stadt- und Universitätsbibliothek und anderer öffentlicher Sammlungen in Frankfurt am Main (Frankfurt-am-Main: Vittorio Klostermann, 1967), 92 (see also 34, 239, 317, 351 for other books from Vasbender's library).

29 Thomson, Catalogue of the Medieval Manuscripts at Peterhouse, xxxviii-xxxix.

30 Peterhouse, MSS 269 and 70; Walker, Admissions to Peterhouse, 48-49.

${ }^{31}$ On such collecting of miniatures, see A. N. L. Munby, Connoisseurs and Medieval Miniatures, 1750-1850 (Oxford: Clarendon Press, 1972), 31-32, 62-68. 32 This copy is now at stuttgart, Württembergische Landesbibliothek, shelfmark Bb lat. 145401. See also The Gutenberg Bible: The Property of The General Theological Seminary, New York City (New York: Christie's, 1978); Christel 
Römer and Gerhard Römer, eds., Bibelhandschriften,

Bibeldrucke: Gutenbergbibel in Offenburg (Offenburg, Ger.: Stadt Offenburg, 1980), 30-34.

33 Christopher Wordsworth, Scholae Academicae: Some Account of Studies at the English Universities in the Eighteenth Century (Cambridge, 1877), 3. The manuscript of Aulus Gellius is now Cambridge, Pembroke College, MS 168. See also Zacharias Conrad von Uffenbach, Merkwürdige Reisen durch Niedersachsen Holland und Engelland, 3 vols. (Ulm, Ger., 1753-54), 3:51-52, 59-60. See also J. E. B. Mayor, ed., Cambridge under Queen Anne (Cambridge: Deighton, Bell, 1911), 169-70, (and 177): "7 Aug. We were in Peterhouse, which, though the oldest college, is yet new and well built. The library is in a poor room of moderate size. The manuscripts stand partly over the door, and at the very top of the cases, and were so buried in dust, that the librarian was forced to send for a towel, for me to wear as a pinafore, that I might not dirty myself too much. They were also in such disorder, that I could find nothing at all by the catal. MSS. Angl. part II. 147 seq. They are mostly scholastica." Uffenbach was trying to use as a guide the listing given in Edward Bernard, Catalogus librorum manuscriptorum Angliae et Hiberniae (Oxford, 1697), pt. 2, $147-55$

34 See Peterhouse, MS 403, and Peterhouse Archives, N. 1. 33, 1-3, for the relevant library rules; see also Peterhouse, MS 
411 for the activity of such scholars in the early eighteenth century

35 Walker, Admissions to Peterhouse, 257; John Venn and J.A. Venn, Alumni Cantabrigienses, Part I: From the Earliest Times to 1751, 4 vols. (Cambridge: Cambridge University Press, 192227), $1: 118$.

36 Walker, Admissions to Peterhouse, 256; Venn and Venn, Alumni Cantabrigienses, 1:409-10.

37 See John Blatchly, The Town Library of Ipswich (Woodbridge, Suffolk: Boydell Press, 1989), 49; Trevor Cooper, ed., The Journal of William Dowsing (Woodbridge, Suffolk: Boydell Press, 2001), 155-61.

$38 \mathrm{~J} . \mathrm{W}$. "Elegy to the Memory of the ingenious Artist Mr. Beeston Coyte," The Gentleman's Magazine 46 (1776): 36-37. 39 Walker, Admissions to Peterhouse, 259; Venn and Venn, Alumni Cantabrigienses, $1: 388$.

40 Walker, Admissions to Peterhouse, 253; Venn and Venn, Alumni Cantabrigienses, $3: 383$.

41 Walker, Admissions to Peterhouse, 263-64; Venn and Venn, Alumni Cantabrigienses, 4:129. For the will of Jaques Spearman (dated June 30, 1745), see Chelmsford, Essex Record Office, MS D/ABW $95 / 2 / 38$.

42 Venn and Venn, Alumni Cantabrigienses, 1:354.

43 Ibid., 4:308-9.

44 Ibid., 1:20-21. 
45 Peterhouse, MS 411, fols. 6r (Beaumont), 14v (Coyte), 23r (Beaumont), $30 r$ (Beaumont), 34 r (Spearman, dated Apr. 2, 1735; also pen trials at the end of the volume). Beaumont's borrowings as a fellow commence on fol. 36r; cooke's on fol. $37 r$.

46 Thomas Gibbons, The New-Blown Bladder Prick'd: Or, A Proper Chastisement of One Jaques Spearman (London, 1740), 9-10 and 5-6 respectively. See also Jaques Spearman, Remarks on a Dialogue, Intituled, Calvinism and Nonconformity Defended (London, 1740) and An Appeal to the Independent Congregation at Royston (London, 1741). For the longevity of Congregationalism in Royston, see Margaret Spufford, Contrasting Communities: English Villagers in the Sixteenth and Seventeenth Centuries (London: Cambridge University Press, $1974)$. 